Jurnal Agroteknologi, Vol. 6 No. 1, Agustus $2015: 1$ - 8

\title{
PERUBAHAN SIFAT KIMIA TANDAN KOSONG KELAPA SAWIT YANG DIFERMENTASI DENGAN EM4 PADA DOSIS DAN LAMA PEMERAMAN YANG BERBEDA
}

\author{
(Changes Of Chemical Properties Compost Oil Palm Empty Fruit Bunch Fermented \\ With Em4 Dosage And Long Different Ripening) \\ ABDUL RAHMAN TOIBY ${ }^{1}$, ELFI RAHMADANI², DAN OKSANA² \\ ${ }^{1}$ Alumni Prodi Agroteknologi Fakultas Pertanian dan Peternakan \\ 2 Dosen Prodi Agroteknologi Fakultas Pertanian dan Peternakan \\ Universitas Islam Negeri Sultan Syarif Kasim Riau \\ Email: rahman.toiby@gmail.com; elfirahmadani@yahoo.co.id; oksana_ry@yahoo.co.id
}

\begin{abstract}
This study was conducted from March to September 2013 at the Islamic State University of Syarif Kasim Sultan Riau and analysis of the chemical properties of compost made in BPTP Riau. This study aims to determine the dose and the duration of fermentation EM4 right to obtain compost oil palm empty fruit bunches with the best chemical properties. Oil palm empty fruit bunches are used are taken from PTPN V Lubuk Dalam and mixed with manure from cattle feces with ratio of 4:1. The method used was descriptive quantitative method consisting of 12 combinations of treatment and 1 control. The parameters measured were the content of $\mathrm{N}, \mathrm{P}, \mathrm{K}, \mathrm{C}$-Organic and $\mathrm{pH}$. The results of this study indicated that EM4 and long curing compost may improve the chemical properties of oil palm empty fruit bunches, which the administration of $20 \mathrm{~mL} / \mathrm{L}$ EM4 and curing 10 weeks old that A3B4 sample produces the best chemical properties. The content of $N, P, K$, and $p H$ of the sample A3B4 respectively: $6,79 \%$, $3,04 \%, 8,08 \%$, and $9,93 \%$.
\end{abstract}

Keywords : Oil Palm Empty Fruit Bunch, Chemical Properties, EM4, Fermentation

\section{PENDAHULUAN}

Tandan kosong kelapa sawit (TKKS) merupakan limbah utama dari industri pengolahan kelapa sawit. Basis satu ton tandan buah segar (TBS) yang diolah akan dihasilkan minyak sawit kasar (CPO) sebanyak 0,21 ton $(21 \%)$ serta minyak inti sawit (PKO) sebanyak 0,05 ton $(5 \%)$ dan sisanya merupakan limbah dalam bentuk tandan buah kosong, serat, dan cangkang biji yang jumlahnya masing-masing $23 \%, 13,5 \%$, dan $5,5 \%$ dari tandan buah segar (Darnoko cit Anwar, 2008).

Pemanfaatan limbah tandan kosong kelapa sawit sebagai alternatif pupuk organik juga akan memberikan manfaat lain dari sisi ekonomi. Untuk perkebunan kelapa sawit pemanfaatan limbah tandan kosong kelapa sawit dapat menghemat penggunaan pupuk sintetis sampai $50 \%$ (Fauzi et al., 2008).

Pengomposan merupakan salah satu cara meningkatkan nilai hara dan menurunkan volume tandan kosong kelapa sawit yang tidak terpakai. Pemanfaatan tandan kosong kelapa sawit sebagai bahan kompos akan menjawab permasalahan akibat menumpuknya tandan kosong kelapa sawit di pabrik, selain itu dapat memberi tambahan keuntungan dari penjualan kompos dan mengurangi biaya penggunaan pupuk anorganik (Darmosarkoro dan Winarna, 2007).

Tandan kosong kelapa sawit yang dikompos secara alami memerlukan waktu cukup lama yaitu sekitar 3 bulan (Darmosarkoro dan Rahutomo, 2007). Hal ini dipengaruhi oleh kandungan penyusunnya yaitu $45,9 \%$ Selulosa, $46,5 \%$ hemiselulosa, dan $22,8 \%$ lignin. Kandungan penyusun tandan kosong kelapa sawit ini sukar untuk terdekomposisi (Darmosarkoro dan Winarna, 2007). Untuk itu diperlukan perlakuan khusus dalam pengomposannya seperti penambahan bioaktivator (Susilawati cit Ichwan, 2007).

Pemberian efektif mikroorganisme-4 (EM4) pada tandan kosong kelapa sawit diharapkan dapat mempercepat waktu pengomposan (fermentasi), karena dengan pemberian EM4 kedalam bahan organik dapat 
menambah jumlah dan jenis mikroorganisme yang berperan dalam proses dekomposisi. Kombinasi perlakuan EM4 dan pupuk organik akan mempercepat perkembangan populasi mikroorganisme di dalam bahan organik tersebut sehingga waktu fermentasinya akan semakin cepat (Ichwan, 2007).

\section{BAHAN DAN METODE}

Penelitian ini dilaksanakan pada bulan Maret 2013 sampai dengan September 2013. Penelitian dilaksanakan di Laboratorium Agrostologi, Industri Pakan, dan IImu Tanah Fakultas Pertanian dan Peternakan UIN Suska Riau. Untuk analisis sifat kimia kompos dilakukan di Balai Pengkajian Teknologi Pertanian (BPTP) Riau.

Bahan yang digunakan dalam penelitian ini adalah EM4, tandan kosong kelapa sawit, pupuk kandang, dan gula merah. Adapun alatalat yang digunakan adalah ember, gelas ukur, termometer, timbangan, terpal, gembor, alat dokumentasi, dan alat tulis.

Penelitian ini dilakukan dalam bentuk percobaan dengan dua faktor, yaitu: dosis EM4 dan lama waktu pemeraman. Peubah yang diamati dalam penelitian ini adalah kadar unsur hara seperti $\mathrm{N}, \mathrm{P}, \mathrm{K}$, dan $\mathrm{C}$-Organik selain itu juga kadar $\mathrm{pH}$ dan suhu pada masing-masing kompos. Data digambarkan atau disajikan dalam bentuk tabel atau grafik dan dibuat persamaan regresinya.

Penelitian ini dimulai dengan pengumpulan bahan tandan kosong kelapa sawit, kemudian dicacah halus dengan ukuran 1-2 cm. Kemudian pembuatan larutan EM4 dengan dosis $0 \mathrm{ml} / \mathrm{L}, 10 \mathrm{ml} / \mathrm{L}$, dan $20 \mathrm{ml} / \mathrm{L}$. Selanjutnya, larutan dicampurkan dengan sampel lalu diaduk agar merata. Sampel kemudian difermentasikan dengan lama pemeraman 4, 6, 8, dan 10 minggu.

\section{HASIL DAN PEMBAHASAN}

\section{Kandungan Nitrogen (N)}

Kandungan $\mathrm{N}$ total yang paling tinggi terdapat pada A3B3 (dosis EM4 $20 \mathrm{ml} / \mathrm{L}$ dan lama fermentasi 8 minggu) dan A3B4 (dosis EM4 $20 \mathrm{ml} / \mathrm{L}$ dan lama fermentasi 10 minggu) yaitu masing-masing $6,79 \%$ dan kadar hara $\mathrm{N}$ total yang paling rendah terdapat pada sampel Kontrol dan A1B1 yaitu masing-masing 0,37\%.
Pesentase $\mathrm{N}$ total pada kompos ini cukup tinggi dari penelitian Yunindanova (2009) yang ratarata hanya berkisar $1 \%$. Tingginya kadar $\mathrm{N}$ pada kompos tandan kosong kelapa sawit ini diduga karena naiknya dosis EM4, nilai pH dan lamanya waktu fermentasi yang menyebabkan peningkatan unsur hara N. Hubungan antara kandungan $\mathrm{N}$ total dengan dosis EM4 dan lama pemeraman dapat dilihat pada Gambar 1.

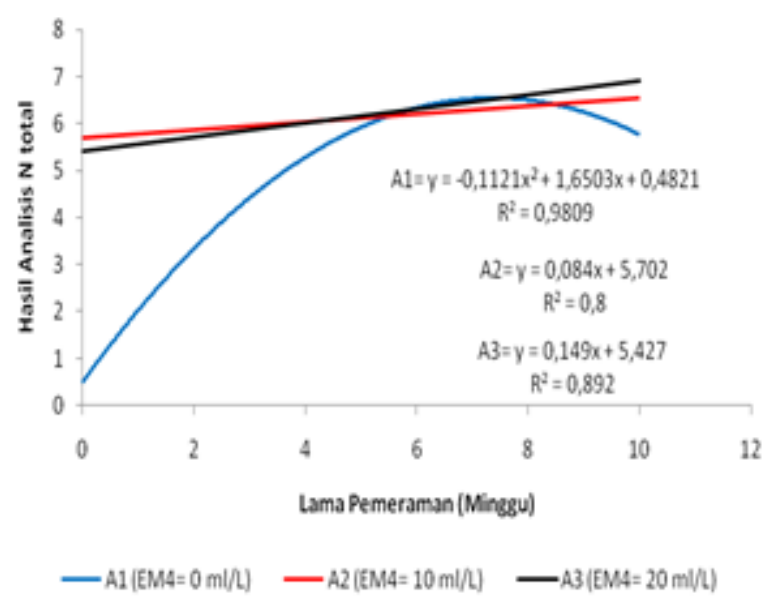

Gambar 1. Kandungan $\mathrm{N}$ total

Dari Gambar diatas dapat dilihat bahwa antara lama pemeraman dengan kandungan $\mathrm{N}$ total dihubungkan dengan dosis EM4 pada $\mathrm{A} 1$ $(E M 4=0 \mathrm{ml} / \mathrm{L}$ ) mengikuti persamaan kuadratik $Y=-0,1121 x^{2}+1,6503 x+0,482$. Dari persamaan ini diketahui bahwa nilai $\mathrm{N}$ - tertinggi adalah $6,56 \%$ untuk persamaan $\mathrm{A} 1$ dan dicapai pada masa pemeraman 7,36 minggu. Untuk sampel A2 (EM4= $10 \mathrm{ml} / \mathrm{L})$ mengikuti persamaan $Y=0,084 x+5,702$ pada sampel $A 2$ yang mana bila lama pemeraman ditambah maka kandungan hara makin meningkat, sedangkan sampel A3 (EM4 $=20 \mathrm{ml} / \mathrm{L})$ persamaan linearnya yaitu, $Y=0,149 x+5,427$.

\section{Kandungan fosfor (P)}

Kandungan unsur fosfor $(\mathrm{P})$ yang paling tinggi pada penelitian ini adalah pada sampel A3B3 (dosis EM4 $20 \mathrm{ml} / \mathrm{L}$ dan lama fermentasi 8 minggu) yaitu $3,13 \%$ dan sampel dengan kadar fosfor terendah terdapat pada sampel kontrol yaitu 0,05\%. Pada Gambar 4.2. dapat dilihat hubungan antara kandungan $\mathrm{N}$ total dengan dosis EM4 dan lama pemeraman. 


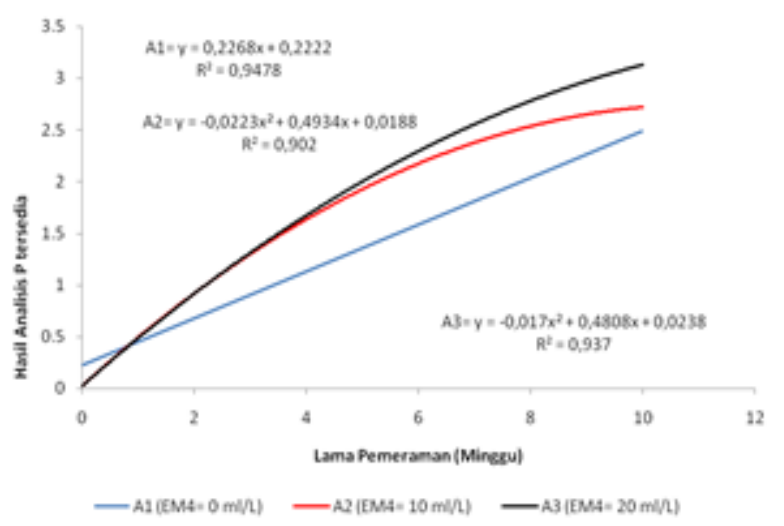

Gambar 2. Kandungan Fosfor

Dari Gambar 2. dapat dilihat bahwa antara lama pemeraman dengan kandungan $P$ dihubungkan dengan dosis EM4 pada perlakuan $A 1$ yaitu pemberian EM4 sebanyak 0 $\mathrm{ml} / \mathrm{L}$ ) juga mengikuti persamaan linear $\mathrm{Y}=$ $0,227 x+0,222$, pada sampel $A 2(E M 4=10$ $\mathrm{ml} / \mathrm{L}$ ) peningkatannya mengikuti persamaan kuadratik $Y=-0,022 x^{2}+0,493 x+0,019$. Dari persamaan ini diketahui bahwa nilai $P$ tertinggi untuk persamaan A2 dicapai pada masa pemeraman 11,06 minggu. Untuk sampel A3 (EM4= $20 \mathrm{ml} / \mathrm{L}$ ) mengikuti persamaan kuadratik $Y=-0,017 x^{2}+0,480 x+0,024$. Dari persamaan ini diketahui bahwa nilai $P$ tertinggi $(3,42 \%)$ untuk persamaan A3 dicapai pada masa pemeraman 14,13 minggu.

\section{Kandungan Kalium (K)}

Kandungan unsur $\mathrm{K}$ yang paling tinggi adalah pada sampel A2B4 (dosis EM4 $10 \mathrm{ml} / \mathrm{L}$ dan lama pemeraman 10 minggu) yaitu 8,33\% dan kadar $\mathrm{K}$ terendah terdapat pada sampel kontrol yaitu $0,34 \%$. Kadar K pada kompos ini juga lebih rendah dari penelitian Yunindanova (2009) yang mana mendapatkan hasil hara Kalium (K) rata-rata 1,19\%. Peningkatan unsur hara $\mathrm{K}$ diduga ada karena penambahan dosis $\mathrm{EM} 4, \mathrm{pH}$, dan lama pemeraman yang dilakukan pada kompos. Peningkatan unsur $\mathrm{K}$ dari kontrol dan sampel A2B4 mencapai 7,99\%.

Antara lama pemeraman dengan kandungan K-dd dihubungkan dengan dosis EM4 pada $A 1$ mengikuti persamaan kuadratik $Y=-0,114 x^{2}+1,844 x+0,611$. Dari persamaan ini diketahui bahwa nilai K-dd tertinggi $(8,40 \%)$ untuk persamaan A1 dicapai pada masa pemeraman 8,09 minggu. Untuk sampel A2 dengan persamaan kuadratik $Y=-0,131 x^{2}+$ $2,055 x+0,3$. Dari persamaan ini diketahui bahwa nilai K-dd tertinggi (8,38\%) untuk persamaan A2 dicapai pada masa pemeraman 7,86 minggu. Untuk sampel A3 persamaan kuadratiknya adalah $Y=-0,147 x^{2}+2,208 x+$ 0,246 , dari persamaan ini diketahui bahwa nilai K-dd tertinggi $(8,54 \%)$ untuk persamaan A3 dicapai pada masa pemeraman 7,52 minggu. Hubungan antara kandungan K-dd dengan dosis EM4 dan lama pemeraman dapat dilihat pada Gambar 3.

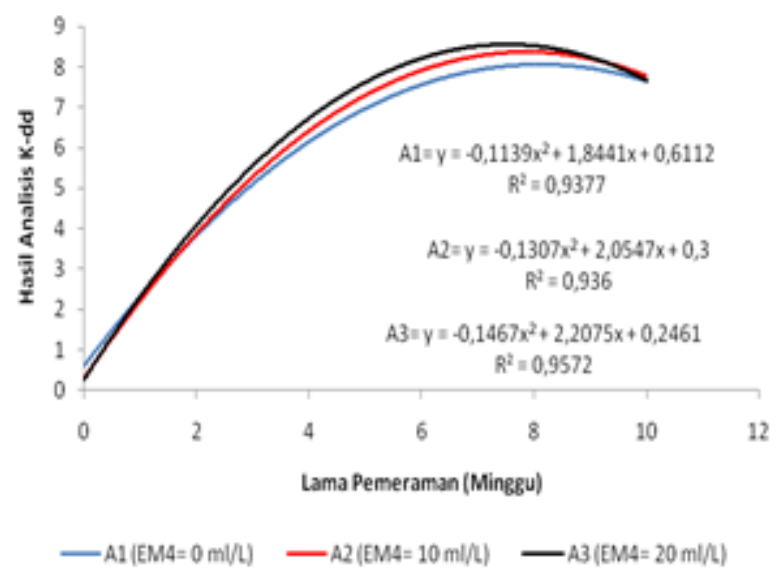

Gambar 3. Kandungan Kalium

\section{Rasio $\mathbf{C} / \mathbf{N}$}

Rasio $\mathrm{C} / \mathrm{N}$ pada penelitian ini diukur dengan membandingkan kandungan C-Organik dengan kandungan $\mathrm{N}$ total. Dimana Kadar $\mathrm{C}$ Organik yang terdapat pada penelitian ini cukup rendah, sedangkan kadar C-Organik tertinggi terdapat pada sampel kontrol yaitu $51,7 \%$ dan kadar C-Organik terendah terdapat pada sampel A3B4 (dosis EM4 $20 \mathrm{ml} / \mathrm{L}$ dan lama fermentasi 10 minggu) yaitu $6,38 \%$. Pada penelitian Darmosarkoro dan Rahutomo (2007) dijelaskan bahwa kandungan Karbon pada kompos tandan kosong kelapa sawit sebesar $42,8 \%$ dan rasio $\mathrm{C} / \mathrm{N}$ kompos sebesar 53. Tingginya rasio $\mathrm{C} / \mathrm{N}$ tersebut disebabkan karena kompos tandan kosong kelapa sawit banyak mengandung bahan-bahan yang sukar terurai seperti lignin dan selulosa.

Kadar C-Organik pada sampel A1 (EM4= $0 \mathrm{ml} / \mathrm{L})$ mengikuti persamaan kuadrat $\mathrm{Y}=$ $0,8188 x^{2}-12,166 x+50,388$. Dari persamaan ini diketahui bahwa nilai C-Organik tertinggi $(5,17 \%)$ untuk persamaan $A 1$ dicapai pada masa pemeraman 7,43 minggu. Pada sampel A2 $(E M 4=10 \mathrm{ml} / \mathrm{L})$ persamaan kuadratiknya adalah $Y=-0,2058 x^{2}+2,7493 x+0,0347$. Dari persamaan ini diketahui bahwa nilai C-Organik 
tertinggi (9,23\%) untuk persamaan A2 dicapai pada masa pemeraman 6,68 minggu dan untuk sampel A3 (EM4=20 $\mathrm{ml} / \mathrm{L})$ persamaan kuadratiknya adalah $Y=-0,1823 x^{2}+2,4185 x+$ 0,1006 . Dari persamaan ini diketahui bahwa nilai C-Organik tertinggi $(8,13 \%)$ untuk persamaan $\mathrm{A} 3$ dicapai pada masa pemeraman 6,63 minggu. Hubungan antara kandungan COrganik dengan dosis EM4 dan lama pemeraman dapat dilihat pada Gambar 4.

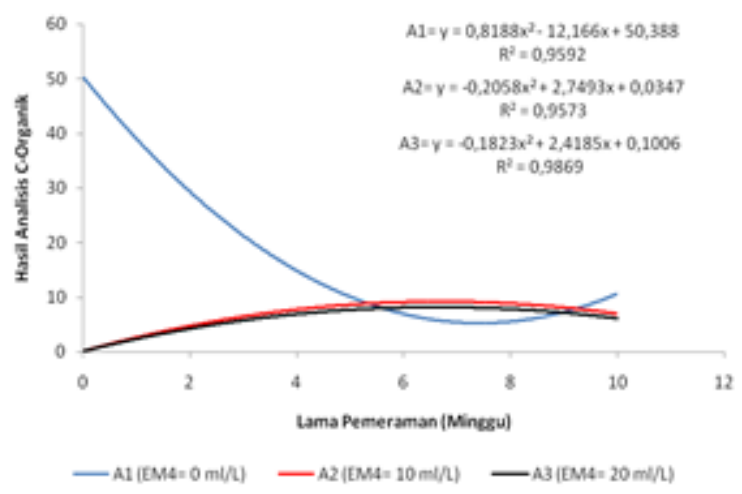

Gambar 4. Kandungan C-Organik

\section{Nilai Keasaman $(\mathrm{pH})$}

Tingkat keasaman $\mathrm{pH}$ pada penelitian ini tinggi dengan rata-rata $\mathrm{pH}$ 9,59. Nilai $\mathrm{pH}$ tertinggi terdapat pada sampel A1B2 (dosis EM4 $0 \mathrm{ml} / \mathrm{L}$ dan lama fermentasi 6 minggu) dengan $\mathrm{pH}$ 10,06 sedangkan sampel dengan nilai $\mathrm{pH}$ terendah terdapat ada sampel kontrol yaitu 7,54. Dosis EM4 dan waktu pemeraman yang berbeda-beda menyebabkan pula perbedaan dari nilai $\mathrm{pH}$ kompos ini. Hubungan antara nilai $\mathrm{pH}$ dengan dosis EM4 dan lama pemeraman dapat dilihat pada Gambar 5.

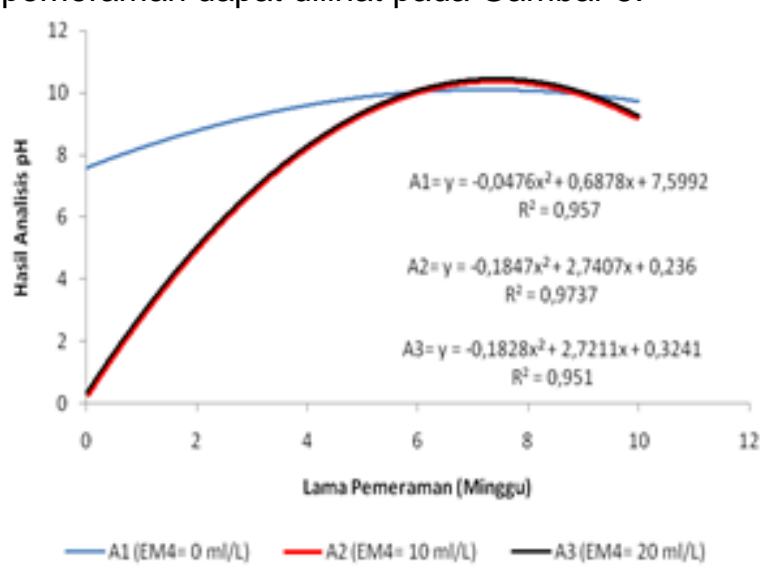

Gambar 5. Nilai pH Kompos

Dari Gambar 5. dapat dilihat bahwa antara lama pemeraman dengan $\mathrm{pH}$ dihubungkan dengan dosis EM4 pada $A 1(E M 4=0 \mathrm{ml} / \mathrm{L})$ mengikuti persamaan kuadratik $Y=-0,048 x^{2}+0,688 x+$ 7,599 . Dari persamaan ini diketahui bahwa nilai $\mathrm{pH}$ tertinggi $(10,08)$ untuk persamaan $\mathrm{A} 1$ dicapai pada masa pemeraman 7,23 minggu. Untuk sampel A2 (EM4=10 ml/L) mengikuti persamaan kuadratik $Y=-0,185 x^{2}+2,741 x+$ 0,236 . Dari persamaan ini diketahui bahwa nilai $\mathrm{pH}$ tertinggi $(10,40)$ untuk persamaan $\mathrm{A} 2$ dicapai pada masa pemeraman 7,42 dan untuk sampel A3 $(E M 4=20 \mathrm{ml} / \mathrm{L})$ mengikuti persamaan kuadraatik $Y=-0,183 x^{2}+2,721 x+$ 0,324 . Dari persamaan ini diketahui bahwa nilai $\mathrm{pH}$ tertinggi $(10,45)$ untuk persamaan $\mathrm{A} 3$ dicapai pada masa pemeraman 7,44 minggu. Menurut Darmosarkoro dan Rahutomo (2007), kompos tandan kosong kelapa sawit dapat dimanfaatkan sebagai bahan pembenah kemasaman tanah karena memiliki $\mathrm{pH}$ yang tinggi (>8). Percobaan yang dilakukan mereka dirumah kaca PPKS dengan menggunakan tanaman jagung sebagai indikator menunjukkan bahwa pada akhir percobaan, penambahan kompos cenderung dapat meningkatkan $\mathrm{pH}$ dan ketersediaan hara seperti $\mathrm{N}, \mathrm{P}$, dan $\mathrm{K}$. tanah yang tidak diberi kompos mempunyai $\mathrm{pH}$ sebesar 5,6-6,0 sedangkan tanah yang memperoleh perlakuan kompos mempunyai $\mathrm{pH}>6,3$.

\section{Suhu Kompos}

\section{Lama pemeraman 10 minggu}

Peningkatan suhu tertinggi terjadi pada sampel A3B4 (dosis EM4 $20 \mathrm{ml} / \mathrm{L}$ dan lama fermentasi 10 minggu) yaitu $39^{\circ} \mathrm{C}$ pada minggu ketiga Banyaknya dosis yang diberikan ternyata membuat peningkatan suhu semakin tinggi. Hal ini diduga disebabkan karena banyaknya jumlah mikroba yang terdapat pada sampel kompos. Perubahan suhu yang terjadi pada kompos merupakan tanda dari aktifitas penguraian bahan organik pada kompos oleh mikroba yang ada pada EM4. Pada tahap awal proses dekomposisidihasilkan suhu kompos yang cukup tinggi. Tingginya suhu ini menunjukkan adanya aktifitas penguraian bahan kimia oleh mikroorganisme termofilik pada EM4 seperti Thermus aquatiqus dalam merombak protein dan karbohidrat nonselulosa, seperti pati dan hemiselulosa (Kharisma, 2006). Peningkatan suhu kompos usia 10 minggu dapat dilihat pada Gambar 6 . 


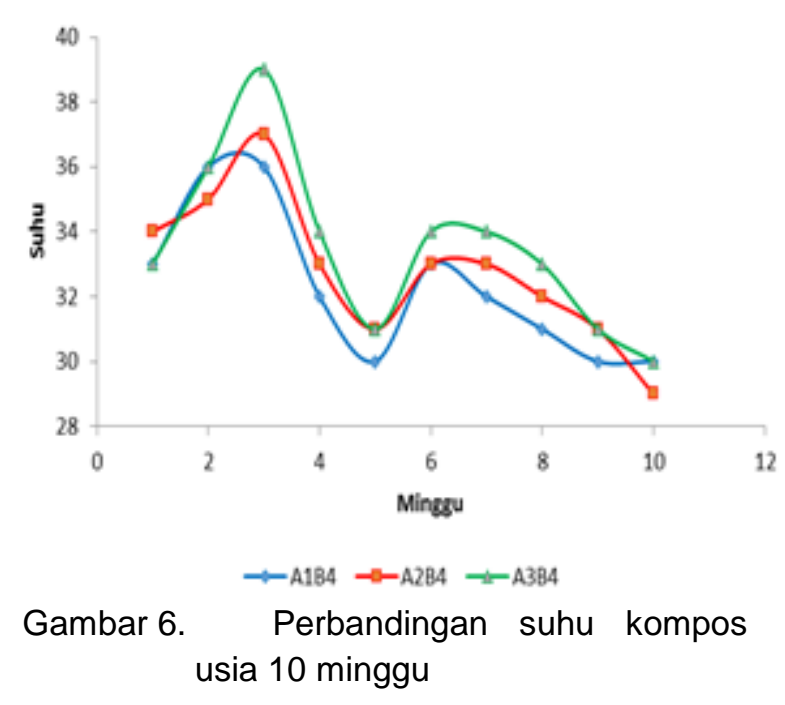

\section{Lama Pemeraman 8 Minggu}

Peningkatan suhu yang tertinggi terjadi pada sampel A3B3 (dosis EM4 $20 \mathrm{ml} / \mathrm{L}$ dan lama Fermentasi 8 minggu) dengan suhu $36^{\circ} \mathrm{C}$ pada Minggu pertama seperti yang dapat kita lihat pada Gambar 7. Diduga peningkatan suhu menjadi tinggi diakibatkan banyaknya mikroba yang terdapat pada sampel karena dosis EM4 yang diberikan tinggi pada penelitian ini. Diketahui, proses pengomposan secara sederhana dapat dibagi dalam dua tahap, yaitu tahap aktif dan tahap pematangan. Selama tahap-tahap awal proses, oksigen dan senyawa-senyawa yang mudah terdegradasi akan segera dimanfaatkan oleh mikroba mesofilik.

Suhu kompos akan meningkat dengan cepat dengan diikuti oleh peningkatan $\mathrm{pH}$ kompos. Suhu akan tetap tinggi selama waktu tertentu. Mikroba yang aktif pada kondisi ini adalah mikroba termofilik, yaitu mikroba yang aktif pada suhu tinggi. Pada fase ini dekomposisi bahan organik sangat aktif. Mikroba-mikroba dalam kompos dengan menggunakan oksigen akan menguraikan bahan organik menjadi $\mathrm{CO}_{2}$, uap air, dan panas. Setelah sebagian besar bahan telah terurai, maka suhu akan berangsur-angsur mengalami penurunan (Subali dan Ellianawati, 2010). Peningkatan suhu kompos usia 8 minggu dapat dilihat pada Gambar 7.

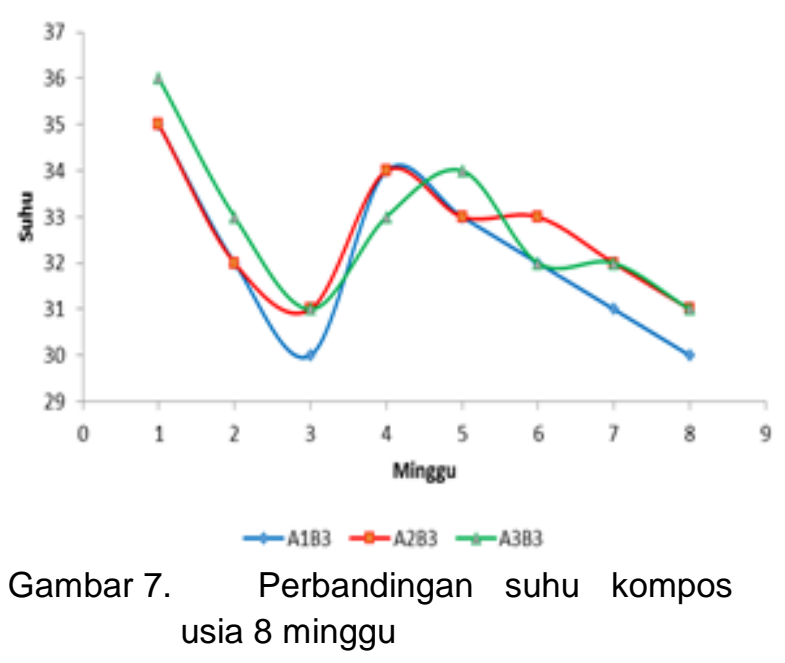

\section{Lama pemeraman 6 minggu}

Pada sampel dengan lama pemeraman 6 minggu didapatkan sampel dengan peningkatan suhu tertinggi terdapat pada sampel yang di beri dosis EM4 $20 \mathrm{ml} / \mathrm{L}$ yaitu pada sampel A3B2 dengan peningkatan suhu mencapai $36^{\circ} \mathrm{C}$ pada Minggu ketiga seperti yang dapat kita lihat pada Gambar 8. Dari hal ini kembali dapat disimpulkan bahwa banyaknya mikroba dalam kompos sangat mempengaruhi kenaikan suhu kompos karena aktifitas penguraian bahan organik yang dilakukan oleh mikroba tersebut terutama mikroba termofilik dalam merombak protein dan karbohidrat nonselulosa, seperti pati dan hemiselulosa (Kharisma, 2006). Peningkatan suhu kompos usia 6 minggu dapat dilihat pada Gambar 8.

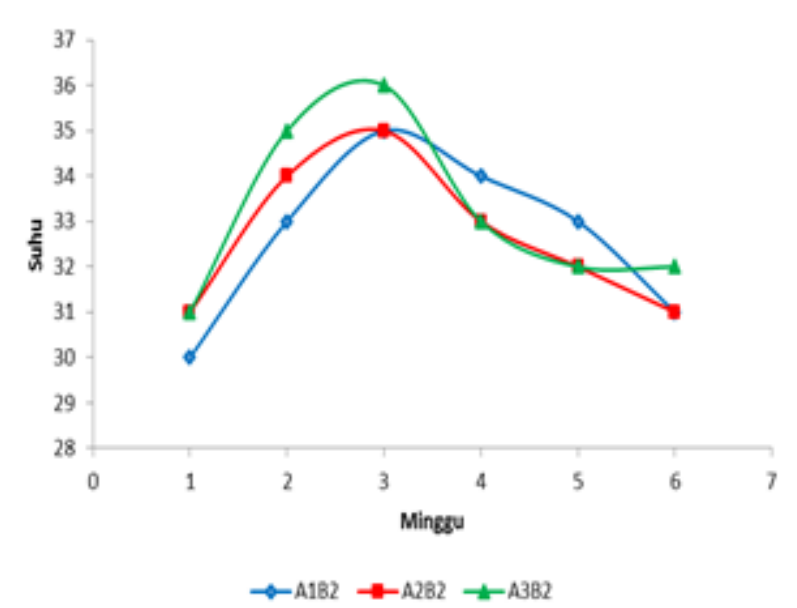

Gambar 8. Perbandingan suhu kompos usia 6 minggu. 


\section{Lama Pemeraman 4 Minggu}

Pada sampel dengan lama pemeraman 4 minggu sampel yang peningkatan suhunya paling tinggi terdapat pada sampel A3B1 (dosis EM4 $20 \mathrm{ml} / \mathrm{L}$ dan lama fermentasi 4 minggu) dengan peningkatan suhu tertinggi mencapai $35^{\circ} \mathrm{C}$ pada minggu kedua. Terjadi peningkatan suhu pada masing-masing sampel kompos di awal pengomposan dan cenderung menurun pada tahap berikutnya. Kenaikan suhu ini terjadi karena adanya aktivitas mikroorganisme dalam mendekomposisikan bahan organik dengan oksigen sehingga menghasilkan energi dalam bentuk panas, $\mathrm{CO}_{2}$ dan uap air. Panas yang ditimbulkan akan tersimpan dalam tumpukan, sementara bagian permukaan terpakai untuk penguapan. Panas yang terperangkap dalam tumpukan akan menaikan suhu tumpukan. Setelah mencapai suhu puncak, suhu tumpukan mengalami penurunan yang akan stabil sampai proses pengomposan berakhir (Hartutik et al, 2008). Peningkatan suhu kompos usia 4 minggu dapat dilihat pada Gambar 9.

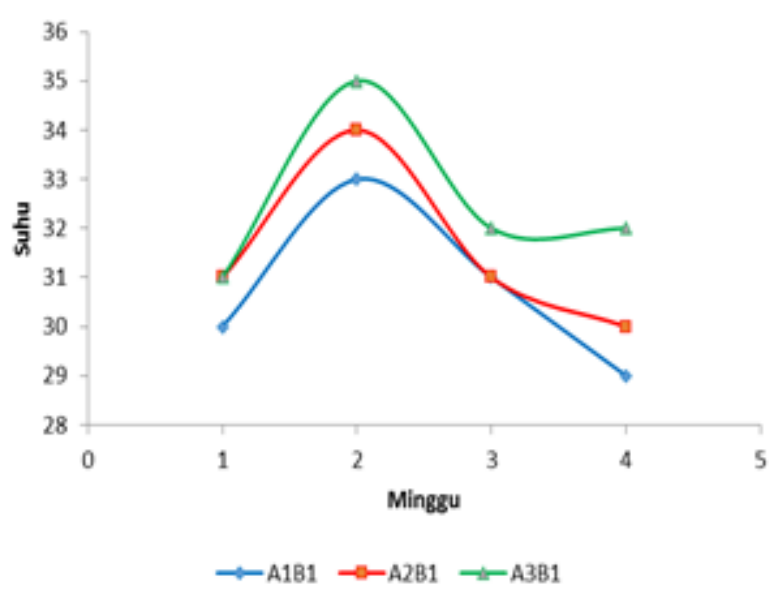

Gambar 9. Perbandingan suhu kompos usia 4 minggu.

\section{KESIMPULAN DAN SARAN}

Kesimpulan:

1. EM4 dan lama pemeraman dapat meningkatkan sifat kimia kompos tandan kosong kelapa sawit, yang mana pemberian $20 \mathrm{ml} / \mathrm{L}$ EM4 dan lama pemeraman 10 minggu (A3B4) menghasilkan sifat kimia terbaik.
2. Terdapat hasil analisis sifat kimia tandan kosong kelapa sawit yang tidak sesuai dengan hasil-hasil penelitian yang ada terutama unsur C-Organik.

3. Kadar C-Organik dan $\mathrm{pH}$ belum sesuai dengan SNI 19-7030-2004 tentang pupuk organik.

Saran:

1. Penggunaan kompos tandan kosong kelapa sawit untuk bahan amelioran pada media tanaman direkomendasikan pada perlakuan A3B4 (dosis EM4 $20 \mathrm{ml} / \mathrm{L}$ dan lama pemeraman 10 minggu).

2. Perlu dilakukan penelitian lanjutan terhadap kandungan unsur hara lainnya dan pengaplikasian kompos langsung pada tanaman.

\section{DAFTAR PUSTAKA}

Anwar, K. 2008. Optimasi Suhu dan Konsentrasi Sodium Bisulfit (NaHSO3) Pada Proses Pembuatan Sodium Lignosulfonat Berbasis Tandan Kosong Kelapa Sawit (TTKS). Skripsi. Fakultas Teknologi Pertanian Institut Pertanian Bogor, Bogor. 87 hal.

Darmosarkoro, W. dan S. Rahutomo. 2007. Tandan Kosong Kelapa Sawit Sebagai Bahan Pembenah Tanah. Jurnal Lahan dan Pemupukan Kelapa Sawit Edisi1. Pusat Penelitian Kelapa Sawit, C3:167180.

Darmosarkoro, W. dan Winarna. 2007. Penggunaan TKS dan Kompos TKS untuk Meningkatkan Pertumbuhan dan Produksi Tanaman. Jurnal Lahan dan Pemupukan Kelapa Sawit Edisi 1. Pusat Penelitian Kelapa Sawit, C4:181-194.

Fauzi, Y., Y.E. Widyastuti, I. Satyawibawa, dan R. Hartono. 2008. Kelapa Sawit: Budidaya, Pemanfaatan Limbah dan Hasil, dan Analisis Usaha dan Pemasaran. Penebar Swadaya. Jakarta. 162 hal.

Hartutik, S., Sriatun, dan Taslimah. 2008. Pembuatan Pupuk Kompos dari Limbah Bunga Kenanga dan Pengaruh Persentase Zeolit Terhadap Ketersediaan Nitrogen Tanah. http://eprints.undip.ac.id/3008/. Diakses tanggal 6 Okteber 2014. 
Jurnal Agroteknologi, Vol. 6 No. 1, Agustus $2015: 1$ - 8

Ichwan, B. 2007. Pertumbuhan dan Hasil Jagung Manis (Zea mays Saccharata Sturry) pada Berbagai Konsentrasi Effektif Mikroorganisme-4 (EM4) dan Waktu Fermentasi Janjang Kelapa Sawit. Jurnal Agronomi, 11 (7): 91-94.

Kharisma, R, A. 2006. Pengaruh Penambahan Bahan Aktif EM4 dan Kotoran Ayam pada Kompos Alang-alang (Imperata cylindrica) Terhadap Pertumbuhan Semai Gmelina arborea. Skripsi. Fakultas Kehutanan Institut Pertanian Bogor. Bogor. 55 hal.

Yunindanova. 2009. Tingkat Pematangan Kompos Tandan Kosong Kelapa Sawit dan Penggunaan Berbagai Jenis Mulsa terhadap Tumbuhan dan Produksi Tanaman Tomat (Lycopersicon esculentun Mill) dan Cabai (Capsicum annum L.). Skripsi. Fakultas Pertanian Institut Pertanian Bogor, Bogor. 76 hal. 
Perubahan Sifat Kimia Tandan Kosong Kelapa Sawit (Abdul Rahman Toiby, et al) 


\section{$\mathbf{J}$

PERUBAHAN SIFAT KIMIA TANDAN KOSONG KELAPA SAWIT YANG DIFERMENTASI DENGAN EM4 PADA DOSIS DAN LAMA PEMERAMAN YANG BERBEDA

Changes Of Chemical Properties Compost Oil Palm Empty Fruit Bunch Fermented With Em4 Dosage And Long Different Ripening

Abdul Rahman Toiby, Elfi Rahmadani, dan Oksana

PEMANFAATAN BEBERAPA JENIS DAN DOSIS LIMBAH KELAPA SAWIT (Elaeis guinensis Jacq) TERHADAP PERUBAHAN PH, N, P, K TANAH PODSOLIK MERAH KUNING (PMK)

Fitri Ramadhani, Ervina Aryanti, dan Robbana Saragih

UPAYA PENINGKATAN HASIL MENTIMUN SECARA ORGANIK DENGAN SISTEM TASALAMPOT

Increasing the Yields of Cucumber by Tasalampot Organic Farming System

Indah Permanasari dan Aulia Rani Annisava

PERTUMBUHAN BIBIT KELAPA SAWIT (Elaeis guineensis Jacq.) DI PEMBIBITAN UTAMA PADA MEDIUM SUB SOIL ULTISOL YANG DIBERI ASAM HUMAT DAN KOMPOS TANDAN KOSONG KELAPA SAWIT

The Growth of Palm Seedlings (Elaeis guineensis Jacq.) at the Experiment Farm By Using Medium Of Subsoil Ultisol That Was Treated With Humic Acid and Fruitless Palm Bunch Compost

Janrico Valentino Sembiring, Nelvia, dan Arnis En Yulia

INDUKSI KALUS PASAK BUMI (Eurycoma longifolia Jack) MELALUI EKSPLAN DAUN DAN PETIOL

Callus Induction of Eurycoma longifolia Jack by Leaf and Petiole Explant

Rosmaina, Zulfahmi, Probo Sutejo, Ulfiatun, dan Maisupratina

KEPADATAN DAN POLA PENYEBARAN PASAK BUMI (Eurycoma longifolia Jack) DI ZONA ALAMAN KUYANG, HUTAN LARANGAN ADAT KENEGARIAN RUMBIO

Density and Distribution Pattern of Eurycoma longifolia Jack) In The Alaman Kuyang Zone of The Forest Reserve of Kenegarian Rumbio

Zulfahmi, Nelawati, Rosmaina 